\title{
As poses, a composição e os acessórios na construção da masculinidade em anúncios publicitários: uma anatomia de poder
}

\author{
Poses, composición y accesorios en la construcción de la masculinidad en \\ los comerciales: una anatomía del poder \\ Poses, composition and accessories in the construction of masculinity in \\ commercial ads: an anatomy of power
}

Leonardo Antonio Soares ${ }^{1}$

\begin{abstract}
Resumo
Várias instituições, incluindo a família, igreja e escola, têm tentando transmitir noções sobre o que é ser "adequadamente" masculino e feminino. Por outro lado, a mídia, através de diversos veículos que incluem revistas, internet, televisão, jornais impressos ou digitais, também contribui para essa inculcação de "gênero", pois através dela a publicidade oferece suas próprias lições, apresentando sugestões sobre como alcançar a masculinidade ou feminilidade ideal. Neste sentido, faz-se crucial que os produtores empreguem diversas estratégias e códigos direcionados ao leitor para assegurar que os objetivos retóricos de persuasão sejam alcançados. O objetivo principal deste artigo é analisar as representações masculinas em épocas e contextos socioculturais diferentes na busca de identificar, através dos micro e macro aspectos, como certos códigos são capazes de transmitir as ideologias de uma época e contexto sociocultural específico. A relevância desse tipo de análise em anúncios publicitários pertencentes a períodos anteriores ao contexto atual está no fato de que tais investigações servem para demonstrar como a masculinidade é concebida em diferentes períodos e contextos socioculturais, levando a uma compreensão maior acerca de seu atual estágio. Para isso, foram selecionados três anúncios publicitários datados de 1969, 1979 e 1997. Para as análises dos anúncios, recorro a autores como Fairclough (1995), que analisa as tendências do discurso midiático, Eckert e McConnell-Ginet (2003) que consideram o discurso como uma atividade social significativa capaz de englobar aspectos verbais e não-verbais, focalizando o discurso dos gêneros sexuais, à multimodalide de Kress e van Leeuwen (2006), que focaliza nos elementos multimodais das imagens e a Callen (1998) que utiliza-se três eixos norteadores (poses e proporções, composição e mídia, e acessórios) para decodificar a linguagem visual. A análise dos anúncios demonstrou que, embora exista um intervalo de tempo transcorrido entre eles, há características em comum no sentido de preservar, fortalecer e enaltecer aspectos da masculinidade tradicional e hegemônica através de micro e macroelementos.
\end{abstract}

Palavras-chave: Anúncios publicitários, Multimodalidade, Códigos, Masculinidade, Mídia.

\section{Resumen}

Varias instituciones, incluida la familia, la iglesia y la escuela, han tratado de transmitir nociones de lo que es ser "adecuadamente" masculino y femenino. Por otro lado, los medios de comunicación, a través de diversos vehículos que incluyen revistas, Internet, televisión, periódicos impresos o digitales , también contribuye a esta inculcación del "género", pues a través de ella, la publicidad ofrece sus propias lecciones, presentando sugerencias sobre cómo lograr la masculinidad o feminidad ideal. En este sentido, es fundamental que los productores utilicen diferentes estrategias y códigos dirigidos al lector El objetivo principal de este artículo es analizar las representaciones masculinas en diferentes

\footnotetext{
${ }^{1}$ Doutor em Linguística Aplicada e Estudos da Linguagem pela PUC-SP. Professor adjunto na Faculdade de Letras da UFMG. Belo Horizonte - MG. E-mail: leons@rocketmail.com
} 
épocas y contextos socioculturales en la búsqueda de identificar, a través de aspectos micro y macro, cómo ciertos códigos son capaces de transmitir las ideologías de un contexto sociocultural específico y tiempo. La relevancia de este tipo de análisis en la publicidad perteneciente a periodos anteriores al contexto actual es el hecho de que tales investigaciones sirven para demostrar cómo se concibe la masculinidad en diferentes periodos y contextos socioculturales, lo que lleva a un mayor entendimiento sobre su etapa actual. Para ello se seleccionaron tres anuncios, fechados en 1969, 1979 y 1997. Para el análisis de los anuncios me refiero a autores como Fairclough (1995), que analiza las tendencias del discurso mediático, Eckert y McConnell-Ginet (2003) que consideran la discurso como actividad social significativa capaz de englobar aspectos verbales y no verbales, centrándose en el discurso de los géneros sexuales, al multimodal de Kress y van Leeuwen (2006), que se centra en los elementos multimodales de las imágenes y a Callen (1998) quien utilizó tres ejes rectores (poses y proporciones, composición y medios, y accesorios) para decodificar el lenguaje visual. El análisis de los anuncios mostró que, si bien existe un desfase temporal entre ellos, existen características en común para preservar, fortalecer y potenciar aspectos de la masculinidad tradicional y hegemónica a través de micro y macro elementos.

Palabras clave: Publicidad, Multimodalidad, Códigos, Masculinidad, Medios.

\begin{abstract}
Various institutions, including the family, church and school, have been trying to convey notions about what it is to be "adequately" male and female. On the other hand, the media, through various resources including magazines, the internet, television, newspapers, etc. also contributes to this inculcation of "gender", because through it, advertising offers its own lessons, presenting suggestions on how to achieve ideal masculinity or femininity. In this sense, it is crucial that producers use different strategies and codes directed to the reader to ensure that the rhetorical goals of persuasion are achieved. The main objective of this article is to analyze male representations in different periods of time and socio-cultural contexts in the search to identify, through micro and macro aspects, how certain codes are capable of transmitting the ideologies of a specific socio-cultural context and period of time. The relevance of this type of analysis in advertising that belong to periods of time prior to the current context is the fact that such investigations serve to demonstrate how masculinity is conceived in different periods and socio-cultural contexts, leading to a greater understanding about its current stage. In order to achieve the aims, three advertisements were selected, dated 1969, 1979 and 1997. For the analysis of the advertisements, I use authors such as Fairclough (1995), who analyzes the trends of media discourse, Eckert and McConnell-Ginet (2003) who consider the discourse as a significant social activity capable of encompassing verbal and non-verbal aspects, focusing on the discourse of sexual genders, to the multimodality of Kress and van Leeuwen (2006), which focuses on the multimodal elements of images and to Callen (1998) who used three guiding axes (poses and proportions, composition and media, and accessories) to decode the visual language. The analysis of the ads showed that, although there is a gap of time between them, they present characteristics in common in order to preserve, strengthen and enhance aspects of traditional and hegemonic masculinity through micro and macro elements.
\end{abstract}

Keywords: Advertisements, Multimodality, Codes, Masculinity, Media.

\title{
1 Introdução
}

Ensinar a ser masculino ou feminino tem sido uma missão conduzida por diversas instituições socias, que incluem a família, a igreja e a escola. A mídia, através de diversos veículos como revistas, comerciais na televisão, anúncios na internet, jornais impressões, etc. também contribui para a reafirmação de regras de gênero devido à sua influência sobre os 
indivíduos, pois é através dela que os anúncios oferecem serviços que trazem implícitas ou explícitas formas de como se chega a um ideal de masculinidade ou feminilidade. Assim como a televisão, os filmes e revistas, os anúncios são construídos a partir do conhecimento social dos produtores, das mudanças socioculturais e das definições de gênero. Já o significado atribuído a um determinado anúncio dependerá de sua interação com o leitor. Por outro lado, focalizar nos anúncios e em seu contexto social e econômico de inserção e produção pode oferecer uma ideia de como a ideologia de gênero foi construída em uma determinada época.

A imagem masculina tem sido apresentada como uma norma, ponto no qual a imagem feminina se desvia. Tal tendência trabalha em favor da naturalização das representações masculinas e das definições de masculinidade. Porém, estudos como os de Kervin (2016), Soares (2015) e Connell (2006), que levam em conta a identidade ${ }^{2}$ masculina e a natureza da masculinidade como construção social, revelam que não há uma única definição, ou imagem masculina, mas um conjunto contraditório que se revela em contextos e épocas diferentes. Sendo assim, o conceito de masculinidade também tem mudado com o passar dos tempos, em reposta a tendências históricas e culturais.

A cada época, uma forma de masculinidade é culturalmente exaltada e Connell (2005) acredita que quando mudam as condições de defesa da patriarquia, as bases de dominação de uma determinada forma de masculinidade são abaladas, fazendo com que novos grupos desafiem a velha ordem e construam uma nova hegemonia. As definições normativas das masculinidades têm como problema que nem todos os homens se encaixam no padrão eleito, mas trazem consigo o aspecto positivo que todos eles irão se beneficiar desta hegemonia. Ainda no que se refere à masculinidade hegemônica, Connell salienta que o corpo exerce papel de destaque na sua construção, sendo violentado em prol das realizações masculinas.

Com relação à masculinidade nos dias atuais, Connell (2005) acredita que nunca se pode falar em uma crise na masculinidade, mas sim em uma ruptura ou transformação. No contexto atual, a heterossexualidade compulsória é forçada aos homens e o corpo deve ser moldado para que tal fim seja atingido. A masculinidade se vê dividida entre as convenções sociais, que podem ser descartadas e as características naturais do corpo, que não podem ser descartadas.

\footnotetext{
2 Bucholz e Hall (2005) definem identidade como o posicionamento social do self e do outro, sendo constituída na interação linguística. Elas sintetizam trabalhos sobre a identidade de várias tradições para oferecer uma perspectiva linguística de cunho sociocultural da identidade-isto é, a que focaliza tanto os detalhes da língua quanto as atividades da cultura e da sociedade. Dessa forma, as identidades sociais são construídas no discurso.
} 
Na história da masculinidade não existe uma estrutura linear, não há tampouco uma transição do tradicional ao moderno e Connell (2005) destaca a existência, desde a antiguidade, de complexas estruturas de relações de gênero onde dominantes, subordinados e marginalizados conviviam em constante interação, com trocas de condições para a existência e transformação uns dos outros. Pelas análises de Connell sobre a masculinidade e seu caráter não permanente lançam luz sobre a razão pela qual se faz importante a análise de anúncios publicitários pertencentes a períodos diferentes e anteriores ao contexto atual, pois tais análises servem para demonstrar como a masculinidade é concebida em diferentes períodos e contextos socioculturais.

Considerando os anúncios publicitários de forma mais direta, parece haver uma variação na construção visual da masculinidade, sugerindo que eles podem ser susceptíveis às mudanças nas crenças sociais sobre os homens. Desta forma, analisar os anúncios se justifica por serem eles sítios de construção de significados que surgem a partir de crenças sociais e ideias, incluindo definições e visões correntes de gênero. A análise de anúncios de diferentes épocas poderá ainda proporcionar um olhar nas mudanças e nas definições de masculinidade relacionadas a audiências e contextos socioculturais específicos.

O objetivo principal deste artigo é analisar as representações masculinas em diferentes épocas e contextos socioculturais na busca de identificar, através dos micro e macro aspectos, como certos códigos como as poses, a composição e os acessórios são capazes de transmitir as ideologias de uma época e contexto sociocultural específico. Para isso, foram selecionados três anúncios publicitários datados de 1969, 1979 e 1997.

Para as análises dos anúncios supracitados, recorro a autores como Fairclough (1995), que analisa as tendências do discurso midiático, Eckert e McConnell-Ginet (2003) que consideram o discurso como uma atividade social significativa capaz de englobar aspectos verbais e não-verbais, focalizando o discurso dos gêneros sexuais, à multimodalide de Kress e van Leeuwen (2006),que focaliza nos aspectos ideacionais, interpessoais e composicionais das imagens e a Callen (1998) que utiliza-se três eixos norteadores (poses e proporções, composição e mídia, e acessórios) para decodificar a linguagem visual. Outros pesquisadores e estudos como os de Kervin (2016), Brod (1987), Rakow (1986) e Morley (1980), que lidam diretamente com a análise das representações masculinas e femininas em anúncios publicitários, também se mostram relevantes para esta análise.

Passo a seguir a uma discussão mais aprofundada da base teórica usada neste artigo. 


\section{Base Teórica}

\subsection{O discurso dos gêneros sexuais}

Eckert e McConnell-Ginet (2003) acreditam que o discurso e a ideologia são inseparáveis, pois ambos são projeções de interesses pessoais em setores sociais específicos. Uma ideologia dominante torna-se bem-sucedida não por sua imposição brutal e consciente de poder, mas pela sua habilidade de "naturalização", nome dado a tudo aquilo que, em uma dada sociedade, não requer uma explicação para ser considerado normal.

Para as autoras, o discurso é uma atividade social significativa que inclui aspectos verbais e não-verbais, na qual as ideias são construídas no decorrer do tempo. O discurso de gênero está relacionado com o trabalho de um conjunto particular de ideias sobre gênero em segmentos da sociedade. Adjetivos como "pretty" e "handsome", em língua inglesa, significam "de boa aparência, bonito" e correspondem a ideais culturais de o que é ser bonito para homem e o que é ser bonito para mulher. "Handsome" é usado para os homens e "pretty" é usado para as mulheres. A escolha vocabular, a pronúncia e os padrões gramaticais sinalizam aspectos relacionados com ideais masculinos ou femininos e possuem alto potencial para reproduzi-los.

A masculinidade, segundo Oliveira (2004), atua no discurso e se constrói como uma estrutura de poder, sendo histórica, ideológica e identitária. Ela predispõe comportamentos ao prescrever atitudes especiais em situações distintas, recorrendo sempre a um sistema de valores. Dessa forma, um tipo de masculinidade se sobressai em determinadas regiões e momentos históricos, mas se modifica ao se fortalecer e, até mesmo, torna-se nulo no contato com outras realidades históricas.

Para Bourdieu (2003), a força da ordem masculina evidencia-se por dispensar justificativa: a ordem social seria uma enorme máquina simbólica que tende a ratificar a dominação masculina. A partir da diferença entre os sexos biológicos, enraíza-se a dominação masculina sobre as mulheres, baseada na divisão do trabalho e na realidade da ordem social. A diferença biológica entre os sexos é vista como justificativa natural da diferença socialmente construída entre os gêneros sexuais. Para o autor, as próprias mulheres aceitam essa realidade nas relações de poder em que estão envolvidas. Os dominados aplicam categorias construídas do ponto de vista dos dominantes, de tal modo que essas relações de dominação são vistas como naturais.

Bourdieu (2003) ainda acredita que a virilidade é entendida como a capacidade reprodutiva, sexual e social, mas também como aptidão ao combate e exercício da violência. 
Nessa perspectiva, atos violentos cometidos por gangues representam uma afirmação de virilidade, e atos de covardia como matar e violentar estão relacionados com o medo da perda da virilidade e da demonstração de fraqueza diante dos outros homens.

Já Falconnet (1975) focaliza o discurso masculino na mídia e aponta a publicidade como um veículo cuja função é realçar qualidades masculinas com adjetivos como energéticos, dinâmicos, eficazes, audaciosos, decididos, resolutos, vigorosos, francos, retos, lógicos, senhores de si, possuidores de caráter e, sobretudo, poderosos. Ao conduzir entrevistas com homens franceses, o autor notou que as qualidades atribuídas pelos meios publicitários se fazem presentes entre eles e são tidas como evidentes e indiscutíveis, mas os entrevistados sentiram dificuldade em defini-las com precisão. Para a maioria deles, ser um homem viril é o mesmo que ser forte, duro e vigoroso.

O homem é quase sempre mostrado como um composto de aventura, guerra, caça, fogo, animais selvagens, cavalos, sensações fortes, vastos espaços, desertos, oceanos, florestas e montanhas; e tais imagens estão associadas a verbos como afrontar, conquistar, cavalgar, dominar, adestrar, domar, empreender, subjugar, agir, submeter, encarar e vencer. A verdadeira vida de homem seria a vida de explorador e conquistador, e o gosto pela aventura permitiria ampliar seu domínio e aumentar sua fortuna. Levar a verdadeira vida de homem não é somente domar os elementos naturais, mas enfrentar os outros homens, já que o universo masculino é movido por armas, competições e lutas pelo poder. Dessa forma, são vendidos perfumes, desodorantes, barbeadores, meias, cuecas etc. - com o produto, o consumidor compra a ilusão de poder, propriedade absoluta do mundo e das coisas.

Muitas pesquisas que analisam os discursos feminino e masculino (ECKERT, MCCONNELL-GINET, 2003; MACNAMARA, 2006; HORSLEY; 2005) mostram que as estratégias discursivas usadas por homens tendem a ser mais competitivas, enquanto as das mulheres tendem a ser mais cooperativas. Da mesma forma, acredita-se que as mulheres devam ser mais educadas que os homens, e estruturas de polidez e afeto aparecem com maior frequência em seus discursos. Dessa forma, o masculino encontra-se associado à razão, e o feminino, à emoção.

De acordo com essa visão, palavrões e outros tipos de interjeição podem expressar intensidade e são vistos como linguagem forte - eles podem alcançar efeitos impressionantes, sendo considerados pontos fortes da linguagem masculina. Expressões de raiva, por exemplo, são esperadas dos homens e toleradas por serem assustadoras e se relacionarem ao controle social através do poder e do medo. 
Por meio da análise de contextos masculinos chega-se à conclusão de que eles são caracterizados pelo que Eckert e McConnell-Ginet (2003) chamam de "linguagem suja", que desempenha papel de destaque nos grupos de homens por reforçar os laços sociais e identitários. Além da linguagem suja, o uso de intensificadores, associados a adjetivos, faz-se presente nos discursos masculinos com a função de reforçar o poder e as atitudes masculinas, estando muitas vezes essa linguagem relacionada à masculinidade da classe trabalhadora.

Para Holmes (1995), os homens tendem a ser menos polidos do que as mulheres em seus discursos, ou seja, usam estratégias que tornam seus discursos mais diretos, sem prestar muita atenção à noção de face ${ }^{3}$. A diferença no nível de polidez ainda depende do sexo do outro participante, e, sendo assim, menor polidez está relacionada com conversas entre homens. As pesquisas ainda sugerem que não há razão para que os homens evitem a linguagem polida, mas que eles o fazem para demonstrar masculinidade. No entanto, acredito que tais diferenças não estejam diretamente relacionadas ao gênero dos participantes, mas a outros fatores sociais como grau de intimidade, contexto em que a conversação ocorre, nível educacional dos participantes e interesses envolvidos. Desta forma, os homens, ao contrário do que Holmes afirma, prestam atenção ao uso da língua em determinados contextos, preservando a ideia de face.

A autora ainda aponta uma segunda razão para o uso de menor polidez por parte dos homens em seus discursos - e, segundo ela, polidez pode estar relacionada a subordinação -: os subordinados tendem a ser mais polidos do que os superiores. A polidez pode variar entre os homens, e aqueles homens menos ligados ao discurso de dominação podem usar linguagem mais polida.

Eckert e McConnell-Ginet (2003) afirmam que, nos aspectos lexicais, as marcas de gênero são bastante complexas e variadas. Dessa forma, palavras associadas ao uso doméstico fazem parte, com maior frequência, do vocabulário feminino; já palavras de uso técnico ou da "rua" fazem parte do vocabulário masculino. Os homens usam mais gírias e palavrões do que as mulheres; já as mulheres devem usar palavras associadas a sentimentos.

Kiesling (2007) investiga como os homens podem usar a língua para expressar sua masculinidade e como a língua pode se tornar mais masculina ou feminina. Ele considera um indivíduo não marcado como sendo um homem branco e pertencente à classe média; para ele, os homens são invisíveis e dominantes ao mesmo tempo, e a isso se deve seu domínio. Eles são dominantes porque são sempre coercivos e por serem padrão na linguagem e na

\footnotetext{
${ }^{3}$ Conceito introduzido por Goffman (1970) que está relacionado com a manutenção de uma imagem pública. Face pode ser definida como um valor social positivo delineada por atributos sociais pré-aprovados.
} 
sociedade. O autor acrescenta que os homens não devem ser vistos como seres invisíveis e não marcados, mas como indivíduos sujeitos aos estereótipos sociais de gênero e linguagem que trabalham duro para manter as aparências e carregarem o peso da masculinidade.

O autor destaca que existem muitas estratégias usadas pelos homens para expressarem ou "criar" heterossexualidade ao falarem com outros homens, como uso de gírias, palavrões, menor polidez, linguagem técnica ou suja etc. Inicialmente, muitos estudos relacionados à linguagem masculina apontaram os homens como menos expressivos linguisticamente, porém estudos mais recentes demonstram que os homens não só são muito expressivos no uso linguístico, mas que usam linguagens e estratégias bastante variadas para atingirem seus objetivos. O que diferencia é que essa expressividade é menos notada devido às normas sociais.

Os anúncios serão analisados pelos viés que considera unir a linguagem usada e sua relação com as imagens na busca de transmitir aspectos ideológicos relacionados à masculinidade de um determinado período e contexto sociocultural e, por tal razão, as considerados de Kiesling (2007) sobre como os homens usam a língua para gerar masculinidade se mostram relevantes para a análise. Neste sentido corroboro a visão de Fowler (1991) que enfatiza que todos reconhecem a importância da língua no processo de construção de identidades, mas na prática a língua recebe um tratamento relativamente pequeno. Por isso, meu objetivo é dar à língua a devida importância, não somente como um elemento de análise, mas também como um modo de expressar uma teoria geral da representação.

\subsection{O discurso da mídia}

Fairclough (1995) aponta três tendências de mudança no discurso contemporâneo da mídia: a democratização, a tecnologização e a mercantilização.

A democratização tem representado um parâmetro para as mudanças discursivas nas últimas décadas. Fairclough aponta áreas principais nas quais a democratização tem sido mais visível: as relações entre línguas e dialetos, o acesso a formas de prestígio do discurso, a eliminação de marcadores de poder em certos discursos institucionais (informalidade maior no uso da língua) e as mudanças linguísticas nas práticas de gênero.

Quanto à tecnologização do discurso, Fairclough (1995) acredita que em entrevistas e anúncios, por exemplo, estão sendo empregadas ferramentas diversas de formas bastante variadas, e tais ferramentas ou tecnologias estão sendo usadas por agentes sociais em 
instituições específicas. Eles detêm o poder, e as tecnologias discursivas desenhadas servem para produzir certos efeitos sobre determinados tipos de público que as desconhecem.

Com relação à mercantilização, a crescente construção do público consumidor e a pressão sobre os produtores para entreter podem ser vistos como parte de uma normalização e naturalização do comportamento e da cultura consumista que envolve anúncios e representações de pessoas em vários tipos de mensagens midiáticas. A mídia, também, influencia as práticas discursivas de domínio privado, fornecendo modelos de interação e estabelecendo relação dialética complexa entre seu discurso e o dia a dia.

\subsection{A masculinidade nos anúncios publicitários}

Rakow (1986) define "gênero" como um processo em andamento e que trabalha para a manutenção das desigualdades na sociedade, fornecendo categorias organizadas que são usadas pelos indivíduos para "fazer sentido no mundo" (p.13). A mesma autora aponta que, apesar da posição de dominação dos homens, existem pelos menos duas implicações a serem consideradas ao analisarmos a imagem masculina na mídia: (a) a natureza sistemática da reprodução ideológica envolve homens e mulheres, ambos estando implicados na manutenção de um sistema. A patriarquia pode ser vista como um construto dentro de cada pessoa e não somente nos homens e, sendo assim, as mulheres também têm a função de legitima-la e (b) embora os homens determinem, de forma mais ampla, a ordem simbólica, existem contradições e mudanças históricas capazes de influenciar suas representações, sugerindo que a masculinidade não é um conceito monolítico.

Por outro lado, Brod (1987) discute a relação entre capitalismo e masculinidade e sugere que as atitudes sociais direcionadas aos homens devem ser vistas em termos de sistema econômico. Sendo assim, mudanças no capitalismo, retirando o poder do indivíduo e transferindo-o às instituições geram muitas implicações para o papel masculino, resultando na contradição entre "o poder público do homem e o sentimento particular de impotência" (p.14).

Através dessa perspectiva, o sistema econômico promete poder em forma de emprego e dinheiro, permitindo o papel do provedor, mas nega acesso ao verdadeiro poder e controle. Isso faz com que os homens se agarrem fortemente aos tipos de identidade masculina válidos ofertados pelo sistema. Ao assumirmos isso, torna-se razoável esperar que haja reforço e talvez mudanças no papel tradicional em determinadas épocas e contextos socioculturais. 
Já os anúncios publicitários, segundo Kervin (2016), existem devido às necessidades do sistema capitalista que precisa manter e aumentar o consumo de determinados produtos. Sendo assim, as empresas acreditam que os anúncios devem ser produzidos e usados, embora não tenha sido realmente comprovada a sua influência real na compra dos produtos. Muitas empresas escolhem anunciar em determinadas revistas, sites ou programas de televisão, etc. baseadas no tipo de público específico que cada uma dessas mídias pode reunir em volta de si, fazendo com que a mídia e os anúncios sejam mutuamente dependentes em seus objetivos econômicos.

Ao buscarem seus mercados e públicos, os anunciantes contam com diferentes sistemas de significado, sendo o gênero considerado um metacódigo (KERVIN, 2016) capaz de influenciar escolhas e capaz de levar ao uso de outros códigos estéticos (cor, iluminação), códigos de moda e não-verbais (expressões faciais, poses) e códigos que indicam papeis sociais (ativo, passivo, chefe, subordinado). Os anúncios são intertextuais por natureza, contando com o conhecimento social e tendências culturais articuladas às teorias de gênero. Historicamente, a visão de gênero em anúncios tem enfatizado a diferença, de forma implícita ou explícita, reafirmando a dissimilaridade entre homens e mulheres.

O metacódigo de gênero pode ser usado até mesmo quando os anúncios não trazem humanos como participantes representados, fazendo uso de outros códigos de representação visual (luz, cor, distância), que irão diferir de acordo com o "gênero do produto" anunciado. Sendo assim, cores e luzes mais suaves podem ser usadas na composição de anúncios direcionados às mulheres, por exemplo. Tradicionalmente, a estrutura de um anúncio incorpora esses diferentes códigos a partir da aposta dos produtores de que os leitores irão ser capazes de decifra-los.

As escolhas dos códigos estão relacionadas com o conhecimento dos produtores dos anúncios, que os direciona aos leitores considerando os conceitos tradicionais de gênero. Em muitos casos, os homens dos anúncios apresentam poses agressivas, firmes ou decididas e olhares direcionados aos leitores, sendo que todas essas escolhas podem reproduzir a posição social de dominação da masculinidade em oposição às tradicionais representações femininas.

Por outro lado, os anúncios publicitários também são estruturados de forma a encorajar, ainda que de forma implícita, os leitores a estabelecerem certas conexões entre o produto e determinados contextos. Eles fornecem materiais crus (sinais) e os enquadram na composição de anúncio, deixando que o leitor estabeleça conexões a partir do processo de produção de significados. 
Morley (1980) afirma que os leitores irão abordar os textos de formas variadas, com base em seu lugar social e em função de seu gênero, classe social, raça e nível educacional. A partir dessa perspectiva, a posição social de cada indivíduo atua de forma a determinar sua interação com um texto e, desta forma, determina também os significados por ele construídos. Sendo assim, dadas as posições diferentes ofertadas a homens e mulheres, pode-se dizer que as leituras dos indivíduos possuem um alto grau de generificação.

Embora os anúncios sejam direcionados a um determinado público e produzidos através do emprego de tecnologias que visam direciona-los ao público idealizado, pode haver algum tipo de rejeição por parte desse público idealizado. Sendo assim, um anúncio direcionado ao público masculino que conta com códigos para atrair esse público, pode não atingir os objetivos de seus produtores.

$\mathrm{O}$ fato de um anúncio ser direcionado a um determinado público, de ele "falar com tal público", faz com que ele possa ser analisado pela perspectiva de como um determinado público-consumidor é construído, que hipóteses são tecidas acerca daquele grupo e quais técnicas e argumentos são tidos como eficazes, sendo capazes de atingir os objetivos. Portanto, os anúncios podem fornecer dicas preciosas relacionadas com as definições sociais de vários grupos, sobre sua situação e posição na sociedade.

Entretanto, Kervin (2016) acredita que as análises de anúncios não podem indicar com precisão como os consumidores realmente leram e entenderam uma determinada mensagem, somente uma análise dos leitores poderia oferecer tais informações. Sendo assim, a pergunta a ser respondida seria: "como os homens e a(s) masculinidade(s) são idealizados nos anúncios? A autora salienta ainda que muitos artigos focalizam em como os anúncios utilizam o sistema de códigos na articulação da masculinidade. Alguns desses códigos são apresentados e debatidos a seguir.

\subsection{As poses, a composição e os acessórios como marcadores de masculinidade}

Callen (1998) relaciona os termos "masculino" e "feminino" a nomes sociais atribuídos em consonância com as características binárias que

trabalham para definir a diferença relacionada a gênero de forma que valoriza-se qualidades específicas em relação à outras. Este processo de diferenciação é cultural, servindo para posicionar homens e mulheres dentro de uma ordem social hierárquica (p.401). 
As representações visuais do corpo são particularmente poderosas neste sentido por elas possuírem impacto direto e imediato. Elas dependem de uma espécie de "vocabulário visual" (CALLEN, 1998: 401) que inclui elementos como marcas, linhas, sombras, cores, etc. Tal vocabulário visual é aprendido e disseminado pelos detentores de privilégios educacionais e culturais que irão compartilhar suas visões e significados, excluindo outras visões.

Sendo assim, as imagens são mediadores potentes de experiências corpóreas, o que inclui nossas próprias experiências e as dos outros, oferecendo formas de conceituar e descrever o corpo. Pode-se assim reconhecer semelhanças e diferenças, fazendo com que cada leitor seja capaz de se identificar, encontrar aquilo que é diferente ou indica poder, reforçar visões e experiências. Para Callen (1998), apesar de todas as análises e da importância de tais imagens na definição de certos conceitos, construção de identidades e experiências, os corpos representados são abstratos, ou seja, são produto de ideias socioculturais e historicamente específicas através das quais os produtores, pela sua formação social, determinam a aparência e os significados, sendo tais elementos posteriormente modificados no ato de consumo. Por tal razão, pode-se afirmar que o ato de fazer sentido do corpo em imagens visuais é um processo dinâmico que está em constante (re)visão.

Callen (1998) conclui que todas as representações do corpo são socialmente construídas, contemplando uma cadeia de ideias que incluem noções de raça, classe e gênero. Para a análise dos corpos autora focaliza nas noções, relações e representações de gênero e propõe que tais análises contemplem três eixos capazes de auxiliar na decodificação da linguagem visual: (a) poses e proporções; (b) composição e mídia; e (c) acessórios.

As poses são significativas no sentido prático (transmitem informações) e no sentido discursivo (fazem referências). Sendo assim, elas nunca são acidentais e a intenção dos produtores das imagens é que elas sejam imediatamente reconhecidas pela audiência. Algumas poses irão sugerir intelectualidade, beleza, força, vulnerabilidade, virilidade, poder, etc. Nas análises de Callen (1998), cujo foco recai sobre o corpo masculino representado em obras de arte, a autora destaca que, no passado, houve uma necessidade para que o homem fosse representado elegantemente, mas que o excesso de delicadeza fosse evitado. Por outro lado, fugia-se das formas consideradas como sendo efeminadas, mas evitava-se poses ou feições que denotassem falta de polidez, preferindo assim a boa forma do corpo, a precisão, a exatidão e a imparcialidade. Quanto às proporções, elas são usadas com vários objetivos que vão desde aumentar o poder da imagem sobre o leitor até tornar esse mesmo leitor poderoso a ponto de ter uma imagem ou representação sob seu poder. 
Já a composição e mídia de transmissão se referem basicamente ao enquadramento e as técnicas usadas, que podem sofrer variações dependendo da mídia de transmissão da imagem (exposição em museu, revista, internet, etc). Por outro lado, tal composição pode ainda ser determinada pelo seu propósito, que poderá contemplar venda de produtos ou transmissão de informações, por exemplo.

Os acessórios são elementos capazes de adicionar camadas de significado ideológico. A relação de tais elementos com o mundo real os torna autênticos. Neste sentido, Callen (1998) enfatiza que as relações são frequentemente estabelecidas por gestos, posições, pano de fundo e, principalmente, por objetos que integram uma composição visual. Estes elementos estão longe de serem estranhos à imagem; pelo contrário, são os responsáveis pela transmissão de significados. Eles moldam a imagem, oferecem uma localização e guiam o leitor para aspectos que necessitam ser destacados.

Com relação às representações masculinas, as imagens estão ligadas à produção cultural de significados, possuindo um papel ideológico ativo na construção de certos ideais de masculinidade como sendo universais e normais. Tais ideias, segundo Callen (1998) exercem impacto formativo no sentido de ordenar e reforçar os papéis hierárquicos e sociais.

\subsection{A multimodalidade}

Kress e van Leeuwen (2006) recorrem à teoria metafuncional de Halliday ${ }^{4}$ e, segundo eles, na perspectiva Ideacional, qualquer modelo semiótico deve ser capaz de representar aspectos do mundo da forma que eles são experienciados pelos indivíduos. As cores usadas na confecção de uma capa de revista e seu significado social podem ser usadas como exemplo dessa perspectiva. Na perspectiva Interpessoal, o modelo semiótico deve ser capaz de projetar relações entre o produtor, o sinal e o receptor do sinal. O modelo semiótico tem a função de representar uma relação social particular entre o produtor e o telespectador ou entre o leitor e o objeto representado. $\mathrm{O}$ olhar dos participantes representados e os ângulos podem ser usados como exemplo. Na perspectiva Textual, o modelo semiótico tem a capacidade de formar

\footnotetext{
${ }^{4}$ Para a GSF, a língua serve para construir, simultaneamente, três significados, ou metafunções, segundo Halliday $(1985 ;$ 1994) e Halliday e Matthiessen (2004). São eles: Metafunção Ideacional, que representa os eventos das orações em termos de fazer, sentir ou ser, por meio do sistema da Transitividade, que envolve: (a) participantes; (b) processos e (c) circunstâncias. Metafunção Interpessoal, que envolve as relações sociais com respeito às relações entre as pessoas expressas na linguagem. Refere-se a dar ou pedir informação ou bens e serviços. Metafunção Textual, que organiza os significados ideacionais e interpessoais de uma oração. Trabalha os significados advindos da ordem das palavras na oração, considerando as escolhas que compõem o Tema e o Rema da oração. Essas metafunções ocorrem ao conjuntamente: cada escolha que fazemos realiza as três metafunções. Portanto, tudo que expressamos linguisticamente contém, simultaneamente, três coisas: a informação (Ideacional), dita a alguém (Interpessoal), de algum modo (Textual).
} 
textos pela complexidade de sinais que se conectam interna e externamente ao contexto para o qual eles foram gerados. Essa perspectiva tem relação com a organização e distribuição dos elementos e inclui a relação entre Dado/Novo e Ideal/Real.A composição relacionada aos significados representacionais e interativos da imagem é agrupada em três sistemas interrelacionados:

(a) Valor da informação: colocação dos elementos (esquerda, direita, em cima, em baixo).

(b) Saliência: os elementos atraem o público em diferentes graus (pano de fundo, frente, tamanho, contrastes de cor etc.).

(c) Moldura: conexão de elementos na figura.

Quanto ao posicionamento dos elementos nas imagens, Kress e van Leeuwen salientam que aqueles elementos que estão colocados à esquerda da imagem podem ser entendidos como "o Dado", ou seja, elementos sobre os quais o público já tem conhecimento; já os elementos colocados à direita da imagem representam "o Novo", ou seja, elementos que estão sendo apresentados ao consumidor.

Em uma composição visual há elementos colocados no topo e outros colocados na parte inferior da imagem. Os elementos colocados na parte superior representam o "Ideal", e os elementos colocados na parte inferior representam o "Real".

O Real apresenta informações detalhadas e práticas próximas da realidade. Se a composição visual faz uso significativo do centro, colocando certo elemento no centro e os demais à sua volta ou às margens, o que se encontra no centro representa, na maioria das vezes, o núcleo da informação.

Independentemente do local em que o elemento é colocado, a saliência cria uma hierarquia de importância, valorizando alguns elementos em relação aos demais.

Kress e van Leeuwen (2006) afirmam que na interação do dia a dia as relações sociais determinam a distância que será mantida em relação ao outro. Para eles, existem diferenças, também, no campo das imagens. De uma distância íntima, podemos ver todo o rosto ou a cabeça. De uma distância próxima pessoal, veem-se a cabeça e os ombros. De uma distância pessoal distante, vê-se até o quadril. De uma distância social próxima, vê-se toda a figura e, de uma distância social distante, vê-se toda a figura, incluindo seu entorno. De uma distância pública distante, vê-se o dorso de pelo menos quatro ou cinco pessoas. 
Os ângulos altos fazem com que o sujeito pareça pequeno e insignificante; sendo assim, o participante interativo tem poder sobre participante representado. Nos ângulos baixos há impressão de superioridade e triunfo do representado sob o interativo.

\section{Metodologia de análise}

Foram selecionados três anúncios publicitários publicados em 1969, 1979 e 1997 com o intuito de analisar as representações masculinas em diferentes épocas e contextos socioculturais na busca de identificar, através dos micro e macro aspectos, como elementos como as poses, as composições e os acessórios são capazes de transmitir as ideologias de uma época e contexto sociocultural específico. O foco em tal período se justifica pelo fato de as análises de anúncios publicitários pertencentes a períodos diferentes e anteriores ao contexto atual, servem para demonstrar como a masculinidade é concebida em diferentes períodos e contextos socioculturais.

Diante da proposta de uma análise que se inicia nos microelementos até atingir os macroelementos, partirei dos elementos multimodais presentes nos anúncios (KRESS E VAN LEEUWEN, 2006). Em seguida, irei identificar como e em que grau os três eixos norteadores apontados por Callen (1998) estão presentes em cada anúncio. Por fim irei analisar se as características do discurso midiático identificadas por Faircough (1995) se fazem presentes nos diferentes períodos de construção dos anúncios. Para a análise dos macroelementos, as demais teorias e definições sobre $\mathrm{a}(\mathrm{s})$ masculinidade(s), identidade masculina e representações na mídia, mostram-se indispensáveis. Passo a seguir à análise dos dados. 


\section{Análise dos dados}

\section{Anúncio 1 - Alert Limão - 1969}

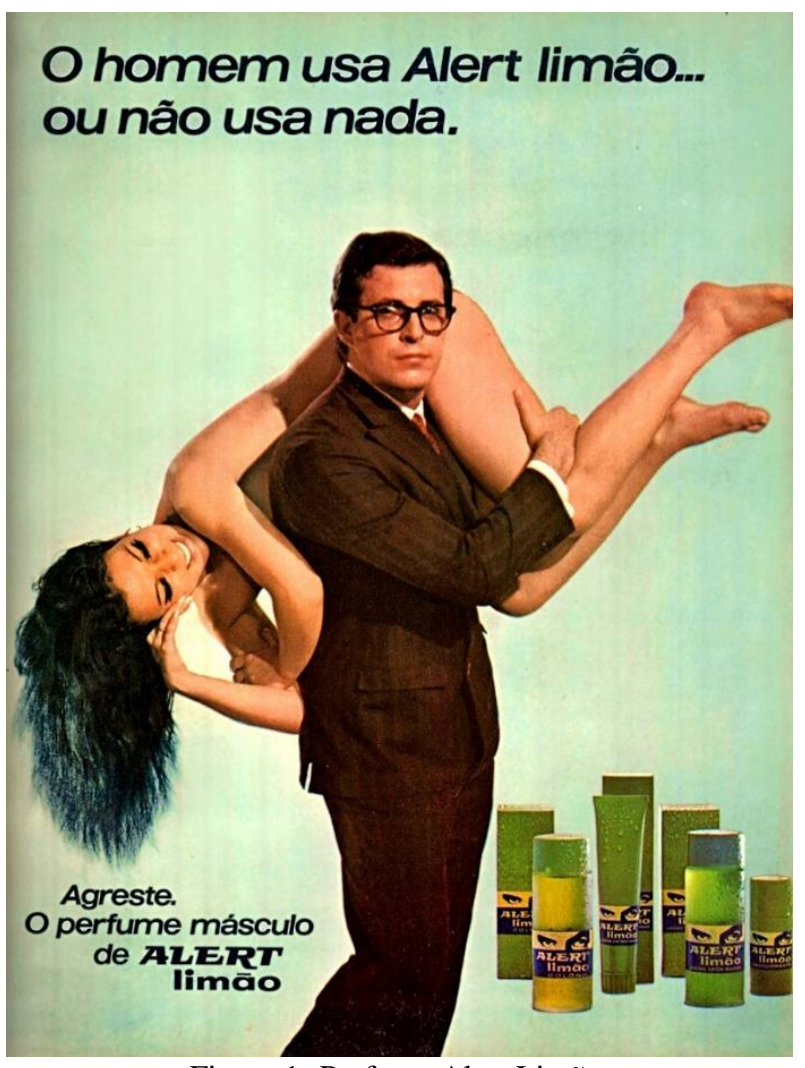

Figura 1- Perfume Alert Limão.

Fonte: https://www.propagandashistoricas.com.br/2018/03/propaganda-antiga-perfume-alert-limao.html Acesso: 27 05-2020.

Masculinidade e feminilidade representam dois extremos no continuum de gênero, com cada membro pertencente a cada extremo sendo exibido a partir de traços, atitudes e interesses, dentro de uma perspectiva normativa considerada ideal em cada período e contexto. Neste caso, tem-se o anúncio de 1969, do perfume masculino Alert Limão, linha agreste. O anúncio foi primeiramente apresentado na revista Ele Ela, de 1969, e pelo fato de ele ter sido primeiramente veiculado em uma revista destinada ao público feminino, pode-se dizer que houve uma inserção do masculino em um espaço que, anteriormente, era ocupado pelo feminino. Isso indica não somente o espaço destinado ao anúncio na revista feminina, mas a inserção dos homens na área de beleza e cosméticos, destinada ao público feminino.

O homem do anúncio (participante representado principal) apresenta olhar de demanda (KRESS E VAN LEEUWEN, 2006) e sua pose denota força, segurança e firmeza nas atitudes. É importante salientar que, em termos de acessórios (CALLEN, 1998), o terno é 
apresentado como traje esportivo, o que naquela época poderia representar uma espécie de interação com o tipo de perfume anunciado.

Em termos linguísticos, a oração "O homem usa Alert Limão...ou não usa nada" representa uma frase entrecortada, também conhecidas como "frases telegráficas", dissimulam sintaticamente o período composto, abrindo, com isso, espaços reticenciosos preenchidos pelo leitor. Em publicidade, tais construções têm o mérito de convocar o receptor a completar seu sentido, valorizando-o. A imprecisão sintática traz vantagens significativas à brevidade, compactando ideias e permitindo a participação do leitor nessa tarefa. Por outro lado, tem-se também o uso de menor polidez, através de uma linguagem direta, neste sentido, Holmes (1995) acredita que a diferença no nível de polidez ainda depende do sexo do outro participante, e, sendo assim, menor polidez está relacionada com conversas entre homens. As pesquisas ainda sugerem que não há razão para que os homens evitem a linguagem polida, mas que eles o fazem para demonstrar masculinidade. Já Kiesling (2007) destaca que existem muitas estratégias usadas pelos homens para expressarem ou "criar" heterossexualidade ao falarem com outros homens, como uso de gírias, palavrões, menor polidez, linguagem técnica ou suja, etc.

Em anúncios que trazem participantes femininas, seu status de subordinação é compensado por algum tipo de sinal de aceitação ou de pertencimento ao contexto e, neste caso, tem-se o sorriso. Neste sentido, Brod (1987) acredita que os homens sejam encorajados a demonstrar características masculinas que irão atuar na manutenção do capitalismo e as mulheres trabalham em conjunto no sentido de auxilia-los nessa construção ideológica de gênero para que possam se beneficiar e continuar o sistema econômico e social. Na mesma direção, Barret (1985) avalia que as mulheres são representadas como se consentissem tal subordinação, possuindo-a de forma internalizada e naturalizada.

Em termos de Fairclough (1995) pode-se dizer que a tecnologização está presente, pois detecta-se que os produtores utilizam técnicas para persuadir e interagir com seu públicoalvo. Nesta linha, detecta-se a mercantilização que vê nesse público a possibilidade de venda do produtor anunciado. 


\section{Anúncio 2-Cuecas Mash - 1979}

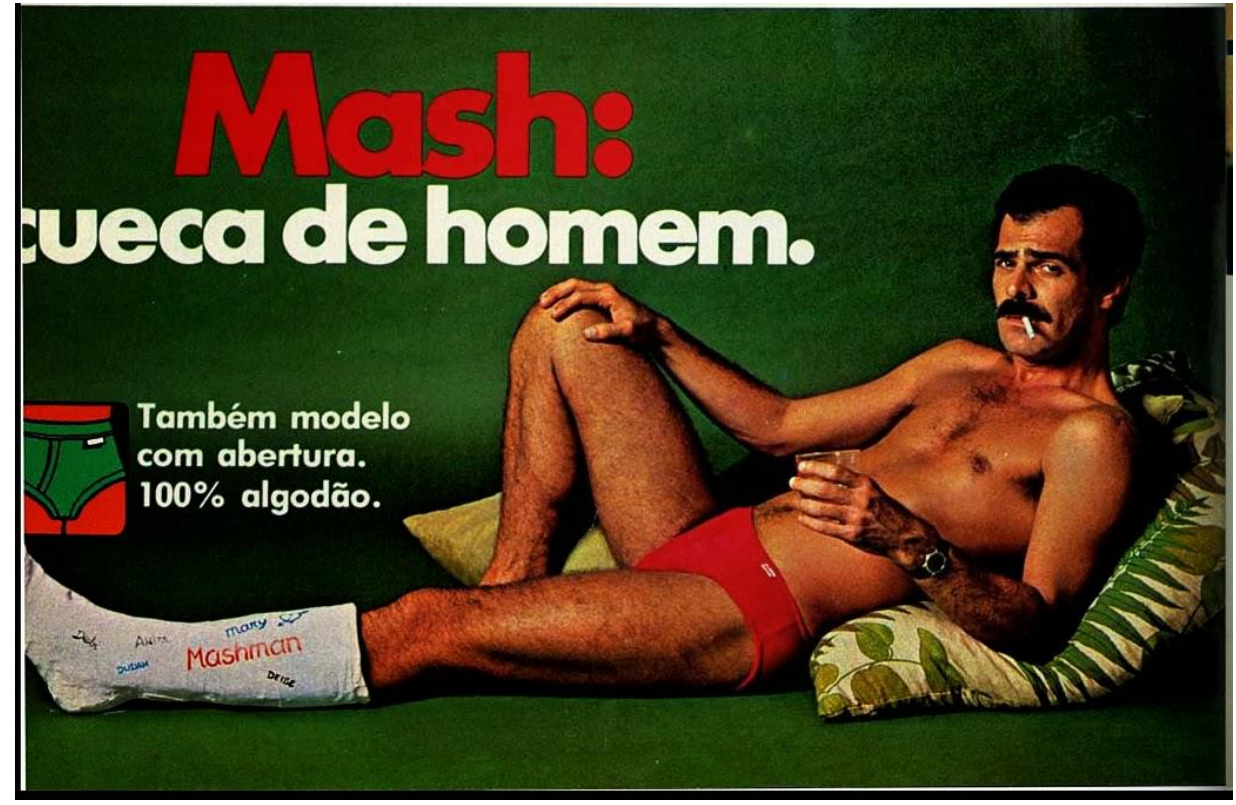

Figura 2 - Cuecas Mash

Fonte: https://www.propagandashistoricas.com.br/2015/11/dez-propagandas-antigas-de-cuecas.html Acesso: 1204-2020.

Neste anúncio de cuecas, de 1979, percebe-se que a exploração do corpo masculino está amplamente relacionada com a visão de masculinidade de época. Em 1979, a erotização do corpo masculino talvez representasse um tabu ou um risco a aceitação do produto, sendo assim prefere-se vender o produto através da imputação de outra identidade ao participante representado: um homem que, a partir dos acessórios como o gesso, copo nas mãos, cigarro e da cueca, se aproxima da masculinidades e dos padrões estabelecidos na época. Ou seja, neste caso, são os acessórios que têm a função de reafirmar sua identidade e papel social, abrindo caminho para sua aceitação. Neste sentido, Callen (1998) destaca que tais elementos estão longe de serem estranhos à imagem; pelo contrário, são os responsáveis pela transmissão de significados. Eles moldam a imagem, oferecem uma localização e guiam o leitor para aspectos que necessitam ser destacados.

Quanto às proporções, elas são usadas em combinação com os acessórios visando aumentar o poder da imagem sobre o leitor, o que em termos de Kress e van Leeuwen, 2006 seria o mesmo que dizer que a imagem está sendo mostrada a partir de um ângulo baixo, a partir de uma saliência e ocupando o centro da composição visual. Ainda a partir das análises de Kress e van Leeuwen, 2006 pode-se dizer que há demanda a partir do olhar do participante representado que, ao mesmo tempo, denota confiança e conforto. Assim como no anúncio anteriormente analisado, detecta-se a mercantilização e tecnologização, mas a ausência da 
democratização, o que pode indicar que tal tendência é usada visando públicos específicos, sendo ela uma tendência mais atual em anúncios.

\section{Anúncio 3 - Cigarros Malboro - 1997}

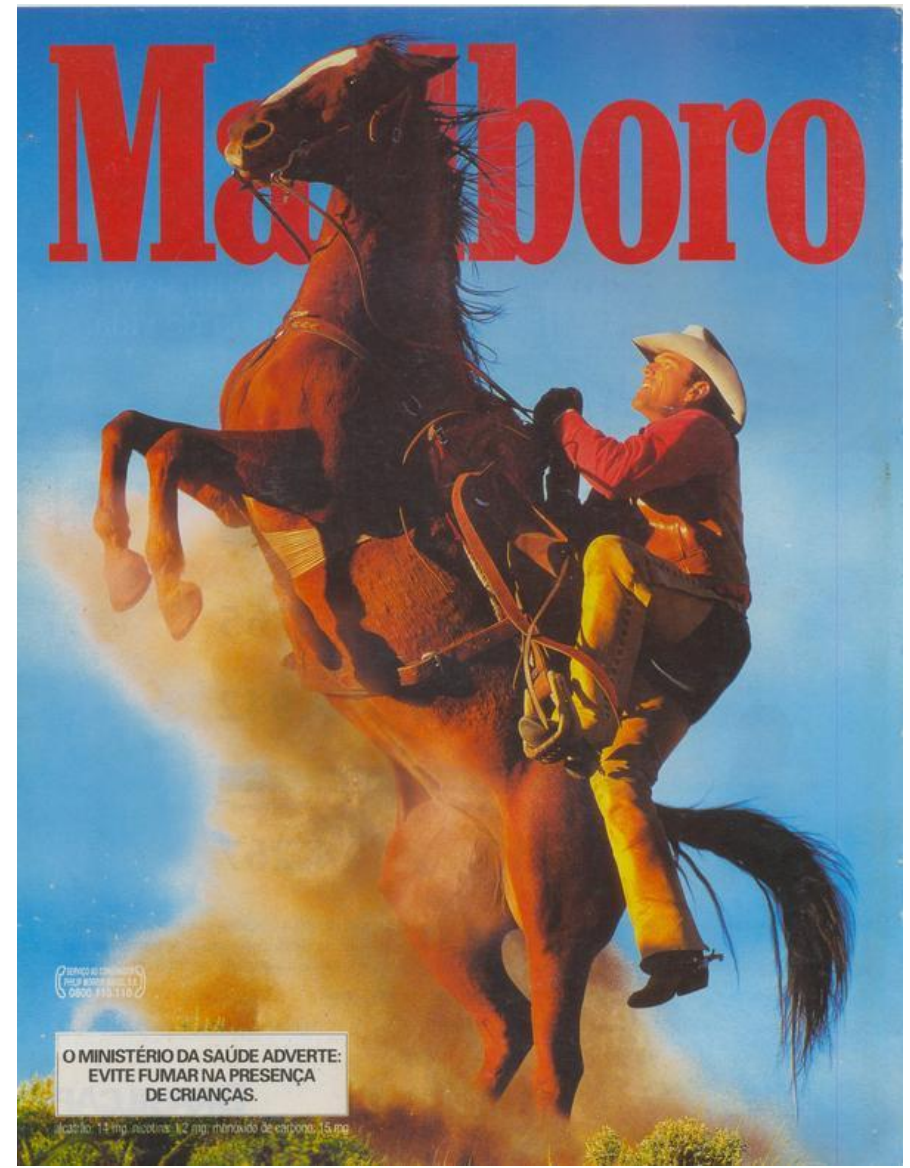

Figura 3 - Cigarros Marlboro.

Fonte: https://www.propagandashistoricas.com.br/2018/03/propaganda-antiga-marlboro.html Acesso: 12-04-2020.

Neste anúncio de cigarros Marlboro tem-se a presença do famoso cowboy que eternizou as propagandas da marca. O anúncio foi veiculado primeiramente na revista IstoÉ, de julho de 1997.

Um estereotipo dominante, alinhado ao sucesso, mostra o homem de forma confiante, autossuficiente e, sobretudo, forte em momentos difíceis. Alguns códigos não-verbais, principalmente corporais, ajudam na demonstração de autoconfiança e tranquilidade, fazendo com que o participante representado se coloque acima de todas as demais figuras, forçando ao leitor admira-lo a partir de um ângulo baixo que denota seu domínio e bravura.

Destaca-se a pose do cowboy do anúncio, que segundo Callen (1998) são significativas no sentido prático (transmitem informações) e no sentido discursivo (fazem referências). Sendo assim, elas nunca são acidentais e a intenção dos produtores das imagens 
é que elas sejam imediatamente reconhecidas pela audiência. Algumas poses irão sugerir intelectualidade, beleza, força, vulnerabilidade, virilidade, poder, etc.

Sendo assim, o participante representado não mantém contato visual com o leitor, oferecendo-o a inserção no universo masculino de força e aventura a partir do uso do produto anunciado. Além disso, a cabeça erguida, os olhos semifechados, demonstram que ele não se importa em ser observado e admirado. $\mathrm{O}$ ato de fumar não é representado somente como atividade, prazer ou lazer, mas traz a mensagem implícita de ser testado, desafiado a se inserir na arena ou grupo daqueles que usam o produto. Isso nos remente a Falconnet (1975), que analisa que os homens são vistos em anúncios e na mídia como um composto de aventura, guerra, caça, fogo, animais selvagens, cavalos, sensações fortes, vastos espaços, desertos, oceanos, florestas e montanhas; e tais imagens estão associadas a verbos como afrontar, conquistar, cavalgar, dominar, adestrar, domar, empreender, subjugar, agir, submeter, encarar e vencer. A verdadeira vida de homem seria a vida de explorador e conquistador, e o gosto pela aventura permitiria ampliar seu domínio e aumentar sua fortuna. Levar a verdadeira vida de homem não é somente domar os elementos naturais, mas enfrentar os outros homens, já que o universo masculino é movido por armas, competições e lutas pelo poder.

O desafio trazido ao leitor pode ser sintetizado em uma pergunta: "você consegue fazer isso/ter esse visual?”. Dessa forma, são vendidos perfumes, desodorantes, barbeadores, meias, cuecas etc. - com o produto, o consumidor compra a ilusão de poder, propriedade absoluta do mundo e das coisas.

Apesar de termos, neste caso, um anúncio mais recente, detecta-se ainda a ausência de democratização apontada por Fairclough (1995), reafirmando o caráter comercial do anúncio a partir dos princípios da mercantilização e da tecnologização.

\section{Conclusão}

Os anúncios representam um dos campos sociais no qual a reprodução de ideologias ocorre. Por serem um campo capaz de exercer grande influência, eles atuam para a manutenção do sistema econômico. Neste contexto, a representação masculina é, na maioria das vezes, simplificada, contando com características tradicionais e dominantes atribuídas aos homens.

Alguns dos estereótipos encontrados nos anúncios analisados ainda sobrevivem, sugerindo que eles sejam relevantes para o preenchimento de necessidades ou na resposta de 
inquietações. Estes mesmos estereótipos continuam a oferecer suas compensações, que indicam admiração, posses, poder, etc., fazendo com que os homens tentem se encaixar nesses espaços e papeis oferecidos.

Ao mesmo tempo, faz-se necessário destacar que novas codificações masculinas surgiram, tais como o uso erotizado do corpo masculino em anúncios publicitários, sugerindo que os anunciantes se mostram atentos às mudanças nas atitudes dos consumidores e do mercado. Isso também indica que a masculinidade não deveria ser vista sob uma perspectiva simples, distante de conceitos históricos, mas como uma construção social em constante movimento.

Porém, o ímpeto por trás dessas representações não-tradicionais não devem ser vistos como o fim dos estereótipos de gênero em representações midiáticas, mas como uma contínua necessidade de se capturar a atenção dos consumidores em dados momentos e contextos socioculturais.

A análise dos anúncios demonstrou que, embora exista um intervalo de tempo transcorrido entre eles, há características em comum no sentido de preservar, fortalecer e, até mesmo, enaltecer aspectos da masculinidade tradicional e hegemônica através de micro e macroelementos. Neste sentido, pode-se dizer que foi atingido o objetivo de análise proposto neste artigo.

\section{Referências}

BARRETT, M. Ideology and the Cultural Production of Gender. In. Newton, J. and Rosenfelt, D. (eds.) Feminist Criticism and Social Change. NY: Methuen, pp. 65-85. 1985.

BOURDIEU, Pierre. A Dominação Masculina. Rio de Janeiro: Ed. Bertrand, 2003.

BROD, H. The Making of Masculinities. Boston: Allen \& Unwin. 1987.

BUCHOLTZ, M.; HALL, K. Identity and interaction: a sociocultural linguistic approach. In. Discourse Studies n. 7, p. 585-614, 2005.

CALLEN, A. Ideal masculinities: an anatomy of power. In. The visual culture reader. Ed. Routledge. London. 1998. p.p 401-414.

CONNELL, R. W. Masculinities. Berkeley: Los Angeles, 2005.

ECKERT, P.; McCONNEL-GINET, S. Language and Gender. New York: Ed. Cambridge, 2003.

FAIRCLOUGH, N. Language and Power. London: Longman, 1989. 
Critical Language Awareness. London: Routledge, 1992a.

Discurso e Mudança Social. Brasília: Editora da UnB, $1992 b$.

Discourse and Social Change. Cambridge: Polity, 1994.

Media Discourse. London: Hodder Arnold, 1995.

Discurso e Mudança Social. Brasília: Editora da UnB, 2001.

FALCONNET, Georges. La Fabrication des Mâles. Paris: Éditions du Seuil, 1975.

FOUCAULT, M. A Ordem do Discurso. São Paulo: Ed. Loyola, 2007.

FOWLER, R. Language in the news. London: Routledge, 1991.

Linguistic Criticism. New York: Oxford, 1996.

HALLIDAY, M. A. K. Language and a Social Semiotic: The social interpretation of language and meaning. London: Edward Arnold, 1978.

An Introduction to Functional Grammar. London: Edward Arnold, 1994.

HALLIDAY, M. A. K.; MATTHIESSEN, C. M. I. M. An Introduction to Functional Grammar. 3. ed. London: Ed. Arnold, 2004.

HALLIDAY, M. A. K; HASAN, R. Language, context and text: aspects of language in a social-semiotic perspective. Oxford: Oxford University Press, 1989.

HOLMES, J. Women, Men and Politeness. New York: Cambridge, 1995.

HORSLEY, R. Men's Lifestyle Magazines and the Construction of Male Identity. 2005. Tese de doutorado. University of Leeds, Institute of Communications Studies.

KERVIN, D. Advertising masculinity: the representation of males in Esquire advertisements. Sage. Pennsylvania. 2016, p. 51-60. Disponível:

https://journals.sagepub.com/doi/abs/10.1177/019685999001400106?journalCode=jcia.

Acesso: $30-05-2020$.

KIESLING, S. Men, Masculinities and Language. Language and Linguistics Compass, p. 653-673, 2007.

KRESS, G.; van LEEUWEN, T. Reading images: The grammar of visual design. London: Routledge, 1996.

. Colour as a semiotic mode: notes for a grammar of colour. London: Sage

Publications, 2002.

Reading images: The grammar of visual design. 2. ed. London: Routledge, 2006.

LI, J. Transitivity and lexical cohesion: Press representations of a political disaster and its actors. Journal of Pragmatics, 42.12, p. 3444-3458, 2010. 
MACNAMARA, J. Media and Male Identity: The Making and Remaking of Men. New York: Ed. Palgrave, 2006.

MIRZOEFF, N. The visual culture reader. Ed. Routledge. London. 1998.

MORLEY, D. The Nation-Wide Audience: Structure and Decoding. London: BFI. 1980.

NOLASCO, Sócrates. O Mito da Masculinidade. Rio de Janeiro: Editora Rocco, 1993.

OLIVEIRA, P. A Construção Social da Masculinidade. Belo Horizonte: Ed. UFMG, 2004.

RAKOW, L. Rethinking Gender Research in Communication. Journal of Communication. vol. 36, no. 4, Autumn, pp. 11-26. 1986.

SOARES, L. A. A masculinidade na capa da revista Men s Health: uma abordagem da linguística crítica sob o enfoque sistêmico-funcional. 2015. Tese (Doutorado em Linguística)

- Pontifícia Universidade Católica de São Paulo, São Paulo, 2015.

VAN DIJK, T.A. Principles of Critical Discourse Analysis. Sage Journal, v. 4, n. 2, p. 249283, 1993. 